\title{
Geomorfológiai tanulmányút a Fogarasi-havasokban - hegyen-völgyön át
}

\author{
(Temesvári Nyugati Tudományegyetem, Temesvár, Románia, \\ 2015. július 13-19.)
}

\section{Tóth Gabriella ${ }^{1}$ - Józsa Edina ${ }^{2}$}

${ }^{1}$ doktorandusz, Pécsi Tudományegyetem, Földtudományok Doktori Iskola, E-mail: toth.gabi90@gmail.com

${ }^{2}$ doktorandusz, Pécsi Tudományegyetem, Földtudományok Doktori Iskola, E-mail: edina.j0zs4@gmail.com

DOI: 10.17799/2016.1.23

Kihasználva a Campus Hungary ösztöndíjprogram csoportos tanulmányutak szervezésére nyújtott támogatását, a Pécsi Tudományegyetem geográfus MSc és földtudományi doktorandusz hallgatói harmadik alkalommal a Déli-Kárpátok felé vették útjukat, hogy a Temesvári Nyugati Tudományegyetem hallgatóinak hagyományos nyári terepgyakorlatán vegyenek részt (1. ábra). A célterület a Fogarasi-havasok, ahol a magashegységi jellegből adódóan alkalom nyílt a 2000 méter fölé nyúló hegyvidéki övezet glaciális és periglaciális formáinak műszeres tanulmányozására. A csoport a tanulmányút során a Bilea-tó (Lacul Bâlea - 2038 m) környékéről indulva csillagtúra-szerűen járta be a környező gerinceket és völgyeket. Az érintett magashegységi terület részletes, többnapos bejárása során a hallgatók példákat láttak a re-

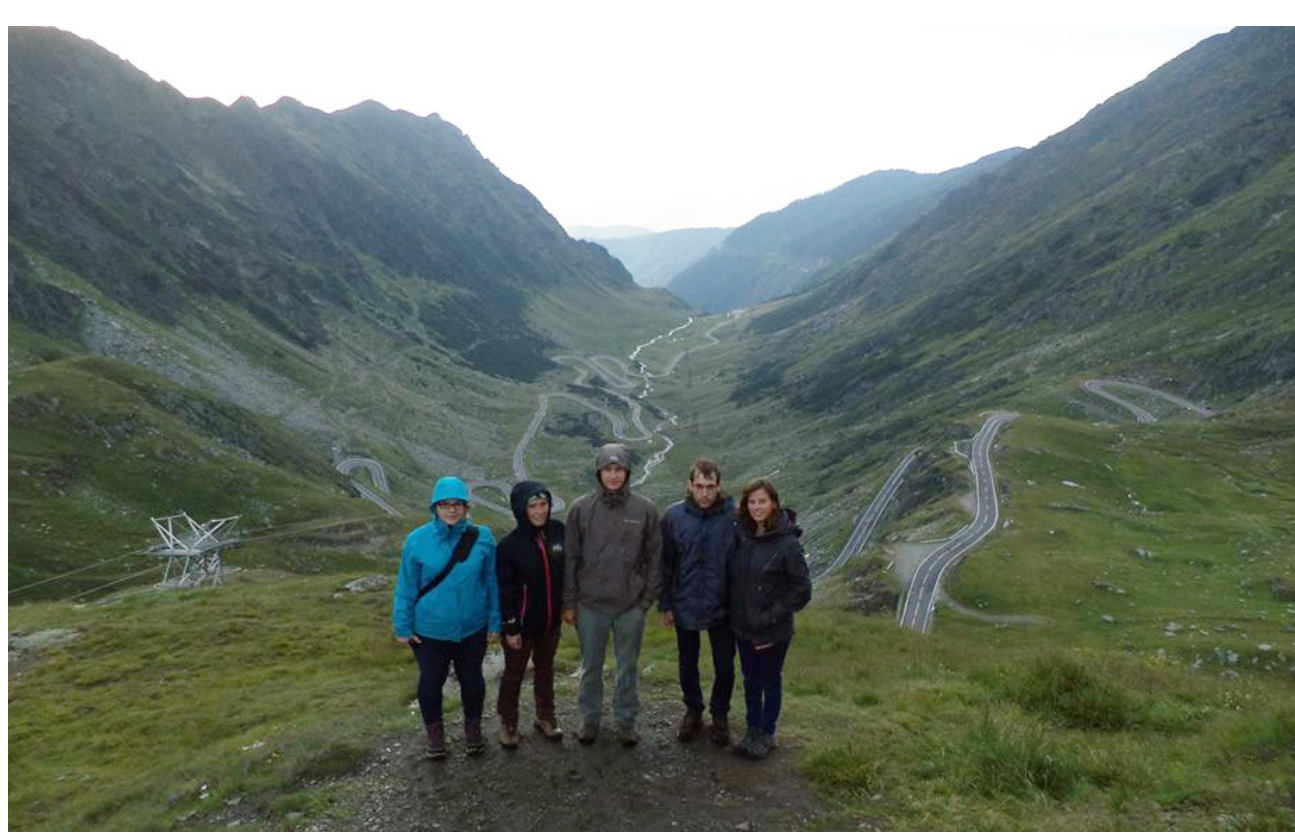

1. ábra: Elszánt hallgatók, háttérben a Transzfogarasi út. (Fotó: Magyar E.) cens és a glaciális völgyfejlődésre, fluviális és fluvioglaciális folyamatok során létrejött eróziós és akkumulációs formákra, a folyóvizek sajátos felszínformálására, valamint a hegyvidéki területhasználat környezetre gyakorolt hatásaira. A csoportot Dr. Petru Urdea (egyetemi tanár, Földrajzi Tanszék), illetve kollégái Dr. Alexandru Onaca és Dr. Florina Ardelean vezette, akik nemcsak geomorfológiai, hidrológiai, talajtani ismereteket nyújtottak, de a környék flóráját és faunáját is megismertették a hallgatókkal.

A Fogarasi-havasok területén a temesvári kutatók kiemelten foglalkoznak a periglaciális folyamatok vizsgálatával, a magashegységi vízgyüjtők posztglaciális fejlődésével, valamint a Transzfogarasi-út mentén zajló változásokkal. A terület geomorfológiai vizsgálata kiemelkedően fontos, mivel a Transzfogarasi-út $90 \quad \mathrm{~km}$-es nyomvonalának kialakításakor a Fogarasi-havasok központi részén a természetes felszíneket átalakították, ami megváltoztatta a lejtők fejlődésének sajátosságait, a napjainkban zajló geomorfológiai folyamatok dinamikáját. Az útbevágások mentén rendszeresen nagy mennyiségü törmelék halmozódik fel, ami a lejtők folyamatos pusztulásának eredménye. A geomorfológiai vizsgálatok sorában ezért a lejtők morfodinamikai sajátosságainak elemzése kiemelkedő, hiszen a megváltozott lejtésviszonyok és a közlekedés okozta folyamatos 


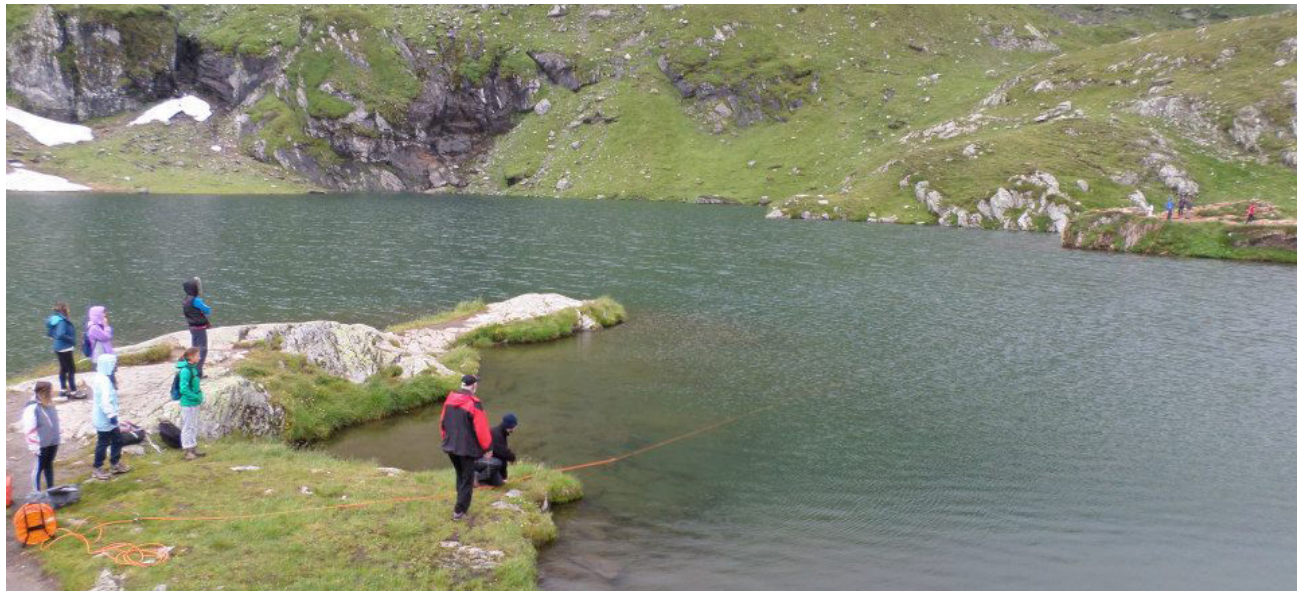

2. ábra: Mederaljzat mérése ERT múszerrel a Bilea-tónál. (Fotó: Józsa E.)

forgalmas turistalátványosság is, hiszen amellett, hogy maga a Transzfogarasi-út a mindöszsze júniustól-októberig terjedő nyitvatartási időszaka alatt sok autózni-motorozni vágyót vonz, a tóparton építtette fel vadászházát Ceaușescu is, amely jelenleg hotellé alakítva a csoport tagjainak is szállást nyújtott.

A második napon a kedvezőbb időjárást kihasználva a Doamnei gleccservölgybe túráztunk el, ahol a haladást a

rezgések miatt megnőtt a területen a tömegmozgásos folyamatok kialakulásának kockázata. A térség turisztikai felértékelődéséből fakadóan egyre több turista jelenik meg a területen, akik a természetes növényzetben való károkozással további lehetőségeket teremtenek a lineáris erózió megindulására.

Az éves rendszeres terepgyakorlatok egy széleskörü, monitoring jellegü kutatásba illeszkednek, amelynek fontos részét képezi a domborzat alapvető morfológiai elemeinek különböző geofizikai módszerekkel (pl. elektromos tomográfia [ERT], földradar [GPR], természetes potenciálmérés [SP], mágneses szuszceptibilitás mérés, termális infravörös fényképezés) történő számszerű és precíz mérése, miáltal vizsgálhatók a különböző felszínformákon és felszínt felépítő anyagokon (pl. glaciális moréna, fluvioglaciális üledékek, periglaciális formák és törmelékek [kőgleccserek], lejtőhordalékok, szoliflukciós üledékek) végbemenő folyamatok. A mérési eredmények kiértékelésére a terepen nem került sor, azonban az oktatók részletesen leírták az elemzésekre használt módszereket, az adatok interpolációjának eljárásait, a kimenetek (diagramok, lejtőprofilok) előállításának módját.

A tanulmányút teljes idejét terepbejárásoknak szenteltük, azonban az első nap kitartó esőzése csupán a szállás környezetének megismerését, valamint a Bilea-tó mederaljzatának ERT eszközzel történő felmérését tette lehetővé (2. ábra). A víz vezetőképessége miatt elegendő volt az elektródakábelt egy kiválasztott keresztmetszetben kifeszítve elvégezni a méréseket. Ezzel a módszerrel a tófenék domborzatát és anyagát, valamint az évente ismételt mérésekkel a feltöltődési folyamatokat is vizsgálják a kutatók. A Bilea-tó környéke egyébként sürü köd és az éles peremü, fagyaprózott törmelék vastag rétege nehezítette meg. Első célunk egy mellékvölgy volt, ahol a magashegységi kisvízgyüjtőkben végbemenő törmelékraktározási és -szállítódási folyamatok monitorozására tettünk előkészületeket (3. ábra). A völgyföhöz közel hálót feszítettünk a völgy aljára, a kijelölt sávban pedig megfestettük a köveket, így a következö terepbejárás során már megállapítható, hogy egységnyi területre mennyi újonnan keletkezett vagy átmozgatott törmelék került. A lepusztulás sebességéről és a törmelékmenynyiség alakulásáról a korábbiakban nem állt rendelkezésre mért adat. Ezt a kutatást vállalta fel egy temesvári doktorandusz, aki a tanulmányút óta már sikerrel meg is védte disszertációját. A nap hátralevő részében a völgy alsóbb szakaszára húzódtunk vissza, ahol a gleccser moréna-anyagát és az általa szállított erratikus tömböket tanulmányoztuk, valamint vezetőink révén a gleccservölgy formálódásáról, valamint a közeli Doamnei-tó (Lacul Doamnei - $1870 \mathrm{~m}$ ) és függővölgy kialakulásának folyamatáról is átfogó képet kaptunk (4. ábra).

A Fogarasi-havasok kristályos palákból és gránitból álló $70 \mathrm{~km}$ hosszú vonulatának, 2000 méter fölötti átlag-

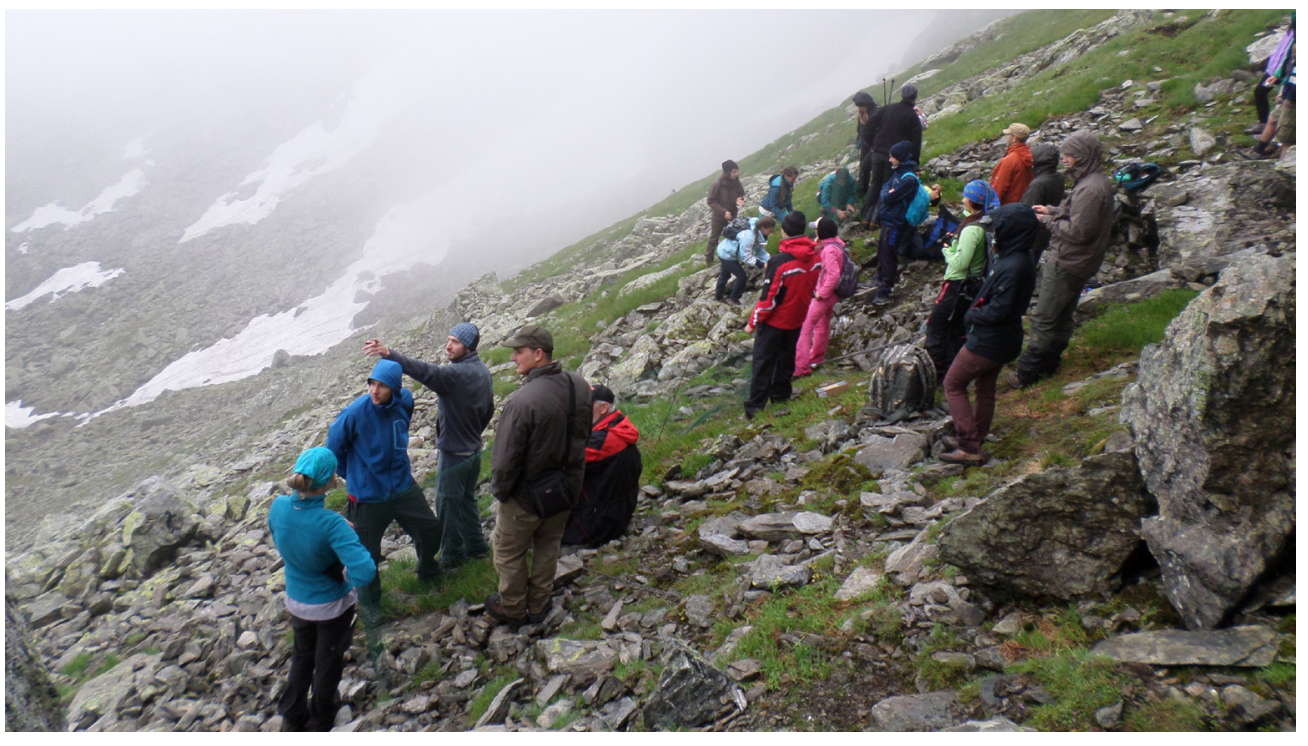

3. ábra: Törmelékmozgás vizsgálatának elôkészítése. (Fotó: Józsa E.) 


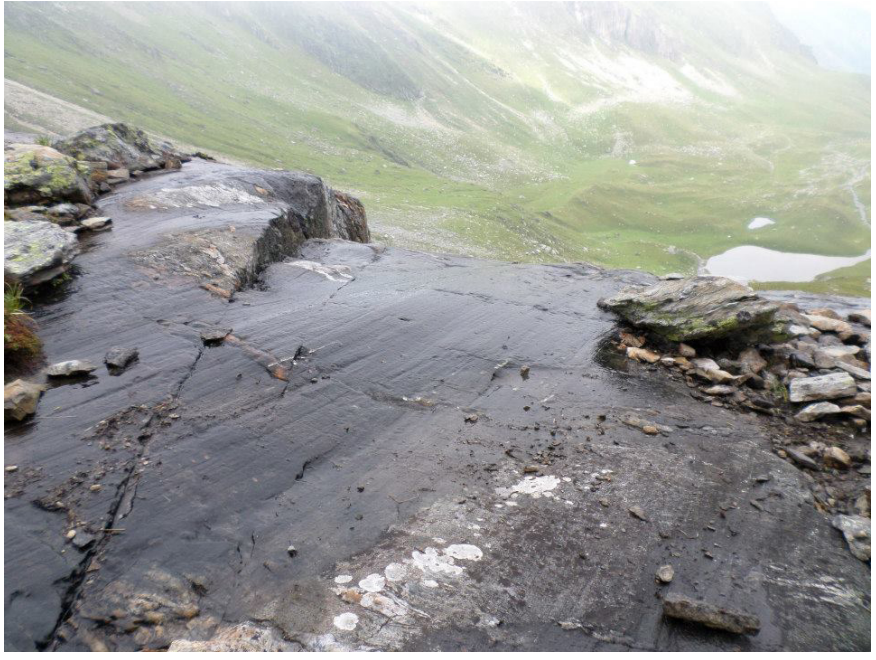

4. ábra: Gleccserkarc a Doamnei-völgyben (Fotó: Józsa E.)

magasságú főgerincéről északi és déli irányba is számos gleccservölgy indul. A pleisztocén jégárak nagymértékben érintették a Déli-Kárpátok területét, az 1700-1800 méter feletti térség eljegesedett, de a kevés csapadék miatt a gleccserek nem futotottak ki a hegység előterébe. A jégkorszak során alakult ki a hegyvonulat sajátos észak-déli aszimmetriája, mivel a jellemző északnyugati légáramlás miatt a jég felszínalakító munkája elsősorban az északi oldalon volt jelentősebb, amelyről a gleccservölgyek és morénaanyag mellett a nyáron is hófoltokkal tarkított számos kárfülke ad tanúbizonyságot.

Másnap egy hosszabb túrával jutottunk át a Paltina - Lăițel (2300-2400 m) területre. Itt a periglaciális képződményeken (pl. szoliflukciós lejtők, fagymintás szerkezeti talajok, törmeléklejtők) végeztünk geofizikai méréseket, valamint a periglaciális folyamatok recens felszínre gyakorolt hatásairól, jelentőségéről is szó esett. A módszerek közül alkalmazásra került az elektromos tomográfiai mérőmüszer, a földradar és mágneses szuszceptibilitás mérést is végeztünk. Ezek célja a lejtők belső szerkezetének feltárása, a periglaciális törmelék vastagságának megállapítása volt. A platófelszínen egyébként

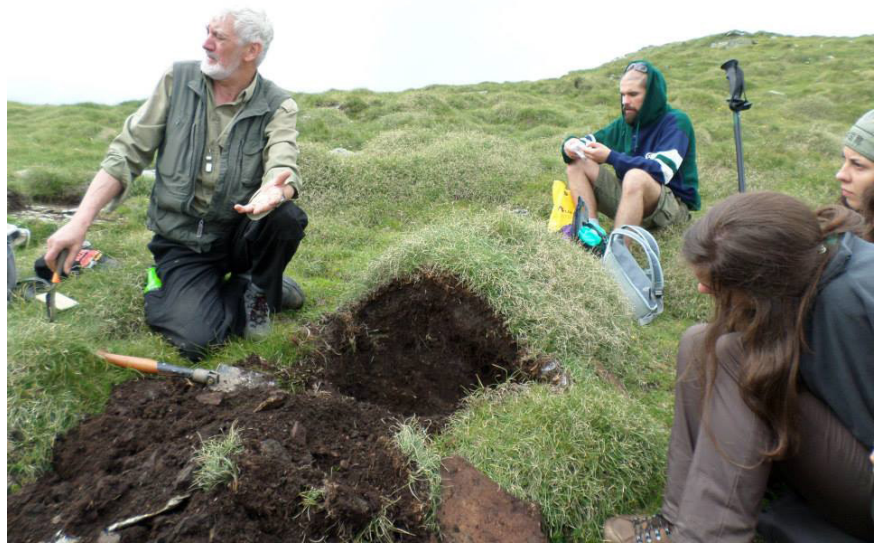

5. ábra: A tufur szerkezetének szemléltetése. (Fotó: Józsa E.) szabad szemmel is jól kivehető, kb. 1,5-2 m átmérőjü poligonális mintázat rajzolódott ki, a szabályos formák a lejtők felé egyre elnyúltabbá váltak. Az ilyen fagymintás szerkezeti talajok, illetve törmeléklejtők vizsgálatában a GPR rendkívül hasznos eszköznek bizonyult, a repedéshálózat eltérő kitöltőanyaga miatt ugyanis ez a speciális forma így nem csak felülnézetben és keresztmetszetekben vizsgálható. Továbbhaladva az enyhén lejtő, kisebb fennsíkokon számos fagypúp, más néven tufur is megjelent. Dr. Petru Urdea tárt fel egy ilyen gyeptakaróval borított, tőzeges-agyagos anyagból álló formát, miközben annak képződését is részletesen elmagyarázta (5. ábra).

A terepgyakorlat zárónapján a Capra-völgy magasabban fekvő részeire tettünk túrát. Innen áttekintve a vizsgált területet átfogó képet kaphattunk a térség komplex geoökológiai rendszeréről. A nap témája volt a bejárt terület összetett magashegységi növény- és állatvilágának bemutatása, a veszélyeztetett fajok problémájának időszerü kérdései és a hegységben zajló transzhumansz gazdálkodás is. A 2230 méter magasságban található Capra-tó (Lacul Capra) egy visszahúzódó tengerszem, melynek alsó, kisebbik mederrészének vízutánpótlása már az olvadás időszakában sem elegendő, így egyre erősebb feltöltődés, tőzegképződés figyelhető meg. A tó környéke kedvelt kirándulóhely. A tóparton az 1960as években hegymászók csoportja emlékmüvet állított az elhunyt alpinisták számára. A turisták jelenléte ellenére, éppen egy hozzánk közeli hófoltra húzódott pihenni a tó névadója, egy kárpáti zerge (Capră-neagră). Továbbhaladva feljutottunk a Fogarasi-havasok ötödik legmagasabb csúcsához, a Butenau-csúcshoz (Vânătarea lui Buteanu), ahonnét a merészebb hallgatók 2507 méter magasságból élvezhették a tájat és a hegység további 2500 méter feletti csúcsainak látványát. A nap végén a Transzfogarasi-út és a Bilea-tó környékének természeti veszélyforrásairól, a természeti katasztrófák kialakulásának kockázatairól is új információkat kaptunk. A törmelékkel borított, meredek lejtőn ereszkedtünk le a müút mellé, így a saját bőrünkön tapasztalhattuk meg milyen nehéz körülmények között és mekkora mértékủ lejtőátalakításokkal lehetett csak ezt a nyomvonalat kialakítani.

A tanulmányút méltó lezárása volt a Campus Hungary ösztöndíj keretében szervezett közös utazásainknak. Remek társaságban (6. ábra), lenyügöző szépségü tájakon haladva szereztünk részletes ismereteket a magashegységek ökoszisztémájáról, geomorfológiájáról és a Pécsi Tudományegyetemen jelenleg elérhetetlen geofizikai müszerek alkalmazásával is megismerkedtünk. A szakmai kapcsolatok mellett baráti szálak is kialakultak a túra résztvevői között, így bizonyosak vagyunk benne, hogy a Temesvári Nyugati Tudományegyetem a jövőben is szívesen fogadja a PTE hallgatóit a Kárpátokba szervezett terepgyakorlatain. Hallgatóinkat csak bátorítani tudjuk, hogy ragadják meg a lehetőséget és bövítsék Földrajzi Intézetünk külföldi kapcsolati hálóját. 


\section{TFK}

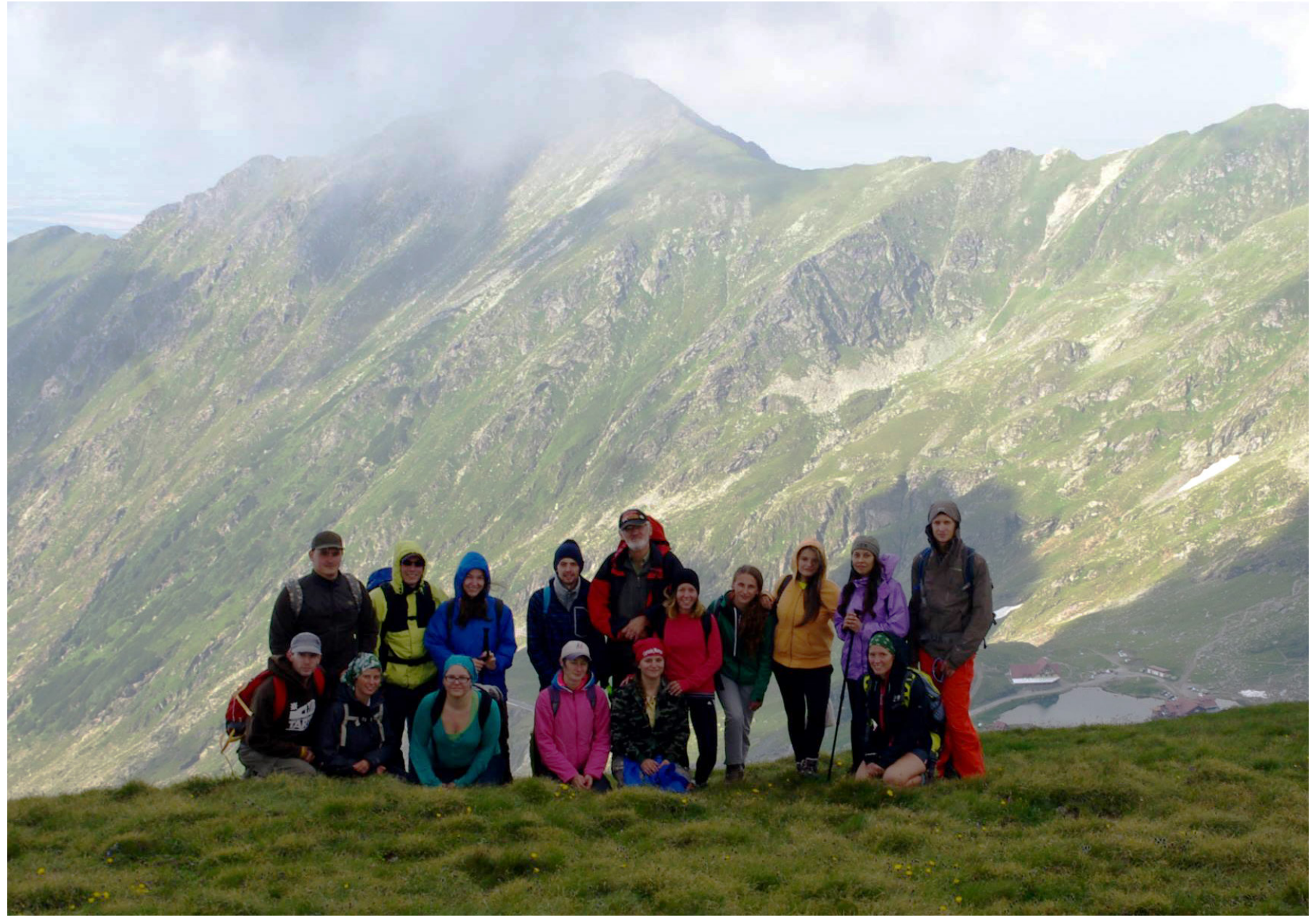

6. ábra: A magyar hallgatókkal kiegészült csoport, háttérben a Bilea-tóval. (Fotó: Stina C.) 
